\title{
Experienced Benefits and Barriers of e-Business Technology Adoption by SME suppliers
}

\author{
Ali Abu Abid ${ }^{1}$, Md Mahbubur Rahim ${ }^{2}$, and Helana Scheepers ${ }^{3}$ \\ ${ }^{1}$ faculty of Computer Sciences, Abha, Saudi Arabia \\ ${ }^{2}$ Caulfield School of IT, Monash University, Australia \\ ${ }^{3}$ Swinburne University of Technology, Australia
}

\begin{abstract}
E-business technologies present unique opportunities and challenges for businesses, and Small \& Medium Enterprises (SMEs) are no exception. However, there is a rich body of the e-business literature concentrates on adoption concerns from SMEs buyers' viewpoint, little research has so far been reported from the viewpoint of SME suppliers. Participation of SME suppliers needs to be ensured in order to use the full potential of e-business technologies. This study was thus initiated to identify the experienced and expected benefits and barriers to adoption of ebusiness technologies from the viewpoint of group SME suppliers. In general, the findings designate that the SME suppliers have experienced numerous impediments that they need to overcome for the successful implementation of e-business technologies. The suppliers also have a broader view of e-business benefits than just cost saving.
\end{abstract}

Keywords: SME supplier, Adoption, Benefits, Barriers, experienced, E-business.

\section{Introduction}

E-business is defined as a business model which enables buyers and sellers to exchange information and services using a range of electronic technologies (Davies \& Garcia-Sierra, 1999). It allows businesses to adjust to novel markets and trade opportunities by increasing their sales, reducing their cost of transactions (Tan et al., 2010) and increasing flexibility in communicating with business partners (Tan et al., 2010; Heung, 2003). Nevertheless, significant difficulties exist for adoption of e-business technologies such as the lack of compatibility between current technical infrastructure and ebusiness technologies (NOIE, 2000).

There exists a rich body of literature on ebusiness for the SME context. However, studies on e-business have not differentiated the benefits and barriers between SME buyers and suppliers. As the business processes associated with fulfillment of suppliers are different from those of ordering and procurement of buyers (Kim, and Shunk, 2004), it is argued that SME suppliers are likely to have different concerns regarding e-business benefits and barriers. Current e-business literature does not report much about the e-business adoption concerns from SME

Copyright (C) 2011 Ali Abu Abid, Md Mahbubur Rahim and Helana Scheepers. This is an open access article distributed under the Creative Commons Attribution License unported 3.0, which permits unrestricted use, distribution, and reproduction in any medium, provided that original work is properly cited. Contact author: Ali Abu Abid. E-mail: abuabid27@hotmail.com 
suppliers' viewpoint. Furthermore, little has been reported about a comparison of expected and realized benefits/barriers from SME viewpoint. This study was thus initiated to better understand the perceptions of SME suppliers about ebusiness technology adoption benefits and barriers by administrating an online survey among a group of SME suppliers which are registered with a large city council located in the estate of Victoria, Australia. Understanding their views is important because participation of SME suppliers is essential if full potential of e-business technologies need to be harnessed.

The overall findings indicate that the impact of e-business technologies adoption is seen in a positive light by the participating suppliers. The SME suppliers have a broader view of e-business benefits than just cost reduction. The findings further confirm that SME suppliers do experience many barriers that they need to overcome for the successful implementation of e-business technologies. However, there is a disagreement in importance between expected and actually encountered barriers. These findings make important theoretical and practical contributions. On the theory side, benefits and barriers of e-business technologies adoption by SME suppliers are identified and comparisons between expected and experienced benefits/barriers are highlighted which has not been specifically addressed in the current e-business literature. The findings thus help in reducing a gap in the literature. The research also indentifies a number of key benefits and barriers that owners and managers of SME suppliers should carefully reflect on when considering the adoption of e-business technologies.

The paper continues with a literature review of e-business technologies adoption benefits and barriers by SMEs. This is followed by a research approach description. Next, results are reported and discussed. Finally, the paper concludes by highlighting contribution, limitations and, future research direction.

\section{Related background literature}

\subsection{Benefits of e-business technologies adoption by SMES}

There is a rich body of literature on ebusiness benefits. A large portion of the literature however discusses benefits without clearly expressing any specific assumptions about business size. In general, the following major benefits are reported in the literature: increased sale (Dubelaar et al., 2005; Scupola, 2009), improved distribution channels (Scupola, 2009; Tan et al., 2010) and improved customer services (Scupola 2009; Osmonbekov, 2010; Tan et al., 2010). These benefits are however likely to be influenced by the capability of businesses to adopt these new technologies. From the resource based view (Grant, 1991); it can be argued that the organizational capability is strongly associated with business size. Recognizing this, benefits of e-business technologies adoption by SMEs are examined by some researchers in recent years (e.g. Quayle, 2002; Drew, 2003; Scupola, 2009; Tan et al., 2010). The following observations can be made by drawing on a review of these studies. First, many of the widely cited e-business benefits advocated by e-business gurus are indeed experienced by SMEs to some extent. Second, their also exists a lack of broad agreement about the attainment of some benefits. For example, Argoneto and Renna, (2010) find increased cost reduction but Tan et al., (2010) present evidence to the contrary. Literature analysis further indicates that some studies acknowledge the need to undertake further investigation to compare benefits of SME buyers and suppliers. For instance, Grover and Ramanlal (1999) highlight that the adoption benefits between buyers and suppliers have not yet been unravelled. Third, no empirical investigations are reported on how various factors affect the attainment of benefits for SMEs context. 


\subsection{Barriers to adoption of e-business technologies by SMEs}

Existing literature identifies numerous barriers to e-business technologies adoption. Similar to e-business benefits, literature is also silent about whether barriers differ based on organizational size. In general, the following major barriers are identified: a lack of time to implement $e^{-}$ business (Scupola, 2009), the high level of complexity associated with e-business implementation (Kaynak et al., 2005) and high implementation cost associated with $e$ business technologies (Gunasekaran and Ngai, 2007; Li and McQueen, 2008; Tan et al., 2010). It is argued that many of these barriers can be successfully addressed by large organizations due to their resource and expertise availability. As SMEs suffer from acute resource scarcity (Riquelme, 2002), the perceived barriers of e-business technologies adoption by SMEs may differ considerably than those of large organizations. As such, some researchers (e.g. Heung, 2003; Tan, Tyler and Manica, 2007; Tan et al., 2009; Tan et al., 2010; Johnson, 2010) examine the barriers perceived by SMEs for introducing ebusiness technologies. According to these scholars, SMEs encounter several barriers cited in the brooder SME literature. However, there is a disagreement about some barriers. For instance, Tan (2007) find a lack of management willingness to engage in e-business to be a major barrier for SME context. But $\mathrm{Li}$ and McQueen, (2008) provide opposite findings. Some scholars acknowledge that barriers to ebusiness technologies adoption among SME buyers and suppliers may differ. For example, Grover and Ramanlal (1999) reported that the barriers to adoption of ebusiness technologies between buyers and suppliers have not yet been untangled. Furthermore, it is unclear wether these barriers have significant influence on ebusiness technologies adoption decision making or implementation stages. Further research is needed to address this concern.

\section{Research approach}

This study used an online survey approach to gain an understanding of SME suppliers' perceptions of benefits and barriers associated with e-business technologies adoption. Online survey was considered appropriate due to: fast access to individuals, increased ability to reach to difficult contact participants, and ease of having automated data collection which reduced researcher time and effort (Wright, 2005). Furthermore, online surveys save researchers money due to the electronic collection of data (Yun and Trumbo, 2000).

The study was conducted in the spirit of the positivist research tradition and followed five stages: literature analysis to develop the theoretical concepts, survey instrument development, instrument evaluation by domain experts, administration of survey and empirical data analysis. From the literature analysis, a set of e-business benefits and barriers were identified. These served as the foundation for developing an initial survey instrument which was divided into four parts: profile of responding managers, characteristic of participating business, expected/experienced benefits of ebusiness technologies adoption, and expected/experienced barriers to adoption of e-business. The instrument was then given to four domain experts (i.e. three ebusiness academics and one senior IT manager from a government organization). They offered a total of 28 suggestions out of which 23 were about improving the clarity and readability of the instrument, 4 were about inclusion of new benefits/barriers related items, and one was about removing a redundant item.

The target survey participants are 3000 SME businesses in Melbourne, Australia, which are registered with a particular city council. The city council provides support for the SME businesses through seminars and delivers relevant information through e-mail. Half of these SME businesses are professional businesses (e.g. accounting organizations) that were not considered suppliers. Out of the remaining 1500 SME businesses, 500 are hairdressers and restaurants which too were not considered suppliers. Thus, the survey questionnaires 
were sent (via email) to the remaining 1000 SME suppliers, out of which 47 SME suppliers responded to the survey, representing a $4.7 \%$ response rate. This low response rate was not considered to be a surprise, given that survey has often been plagued by low response rates (Church, 1993). Moreover, other Australian IT scholars have also reported a low response rate. For instance, Lin and Pervan (2003) reported a $7 \%$ survey response rate while investigating IS/IT benefits among Australian largest 500 companies. Access to the SMEs was obtained by contacting business development manager of the council who was responsible for organizing seminars for SME businesses. Due to privacy concerns, the development manager sent an email to the $1000 \mathrm{SME}$ suppliers requesting their participation in an online survey prepared by authors.

\section{Results}

The research findings were analyzed using a well known statistical package, SPSS version 16. Descriptive, student t-tests and comparative means analysis were performed to analyze the survey data.

\subsection{Participants' profile}

Table 1 provides a summary of the key characteristic about participating respondents. A large majority of the respondents (70.2\%) are owner managers. A slight dominance of male respondents is observed. The distribution of the participating mangers in terms of their working experience with their businesses is well represented for all groups.

\subsection{Characteristic of participating businesses}

A majority of the surveyed suppliers (55.6\%) have an employee dedicated to the IT function. Most suppliers have access to the Internet and have a web presence on the Internet. All suppliers update their websites on a regular basis. Table 2 shows the key characteristics of the participating businesses.

Table 1: Participant Demographic

\begin{tabular}{|c|c|c|}
\hline Managers & Frequency & Percent \\
\hline $\begin{aligned} \text { Job Role } & \\
\bullet & \text { Owner } \\
\text { - } & \text { CEO } \\
\text { - } & \text { Senior business } \\
& \text { manager } \\
\text { - } & \text { IT manager }\end{aligned}$ & $\begin{array}{r}33 \\
7 \\
5 \\
2\end{array}$ & $\begin{array}{c}70.2 \\
14.9 \\
10.6 \\
4.3\end{array}$ \\
\hline $\begin{array}{cl}\text { Gender } & \\
\bullet & \text { Male } \\
\bullet & \text { Female } \\
\end{array}$ & $\begin{array}{l}25 \\
22 \\
\end{array}$ & $\begin{array}{l}53.2 \\
46.8 \\
\end{array}$ \\
\hline $\begin{array}{c}\text { Years with the organization } \\
\text { - } \quad<1 \text { year } \\
\text { - } \quad 1-5 \text { years } \\
\text { - } \quad 6-10 \text { years } \\
\text { - } \quad \text { Over } 10 \text { years }\end{array}$ & $\begin{array}{r}12 \\
15 \\
7 \\
13\end{array}$ & $\begin{array}{l}25.5 \\
31.9 \\
14.9 \\
27.7\end{array}$ \\
\hline
\end{tabular}


Table 2: Characteristic of participating businesses

\begin{tabular}{|c|c|c|}
\hline Characteristic & Frequency & Percent \\
\hline $\begin{aligned} & \text { IT people } \\
& \bullet \quad \text { Yes } \\
& \bullet \text { No } \\
&\end{aligned}$ & $\begin{array}{l}25 \\
20\end{array}$ & $\begin{array}{l}55.6 \\
44.4 \\
\end{array}$ \\
\hline \begin{aligned} & \multicolumn{2}{l}{ Website present } \\
&$\bullet$ Yes \\
&$\bullet$ No \\
&\end{aligned} & $\begin{array}{l}34 \\
12 \\
\end{array}$ & $\begin{array}{l}73.9 \\
26.1 \\
\end{array}$ \\
\hline $\begin{array}{c}\text { Update frequency of websites } \\
\bullet \quad \text { Once a month } \\
\bullet \quad \text { Twice a month } \\
\bullet \quad \text { Every three months }\end{array}$ & $\begin{array}{r}20 \\
6 \\
8\end{array}$ & $\begin{array}{l}58.8 \\
17.6 \\
23.5\end{array}$ \\
\hline
\end{tabular}

\subsection{Expected and experienced benefits}

Table 3 offers a comparison between the mean scores and ranks for both expected and experienced benefits of e-business technology adoption by the participating suppliers. The results indicate the presence of a broad agreement in the top five rankings between expected and experienced benefits. For example, an improved customer service is ranked (1) in the list of expected benefits of e-business technology adoption by SME suppliers, while it is ranked (2) in the experienced benefits. The opposite is observed with increased ability to compete, which is ranked (2) in expected benefits, whereas it is ranked (1) in experienced benefits. Inaddition, increased sales is ranked (3) in expected benefits, while it is ranked (1) in experienced benefits. Greater access to join a wider range of markets is ranked (3) in both expected and experienced benefits, improved distribution channels (rank 4) and increased flexibility in communicating with business partners (rank 5) have the same ranks in both expected and experienced benefits of e-business technology adoption by the suppliers.

\subsection{Expected and experienced barriers}

Table 4 compares the mean scores and ranks for expected and experienced barriers to e-business adoption by SME suppliers. The first five ranks in both expected and experienced barriers to ebusiness technology adoption by SME suppliers are categorized as internal barriers, whereas, external barriers attained the lowest ranks. This observation indicates that the external barriers are neither considered important nor they are frequently encountered, while internal barriers are considered to be more important. Another interesting observation is a lack of correspondence between expected and actually experienced barriers. 
Table 3: Expected and Experienced Benefits

\begin{tabular}{|c|c|c|c|c|c|c|c|}
\hline \multirow[t]{2}{*}{ Benefits } & \multicolumn{2}{|c|}{$\begin{array}{l}\text { Expected } \\
\text { Benefits }\end{array}$} & \multicolumn{2}{|c|}{$\begin{array}{l}\text { Experienced } \\
\text { Benefits }\end{array}$} & \multirow{2}{*}{$\begin{array}{c}\text { Rank } \\
\text { Difference }\end{array}$} & \multirow{2}{*}{$\begin{array}{c}\text { Mean } \\
\text { Difference } \\
\text { (P-Value) }\end{array}$} & \multirow[t]{2}{*}{ Remarks } \\
\hline & Mean & Rank & Mean & Rank & & & \\
\hline $\begin{array}{l}\text { Improved customer } \\
\text { services }\end{array}$ & 2.11 & 1 & 2.47 & 2 & -1 & 0.36 & $\begin{array}{c}\text { Not } \\
\text { significant }\end{array}$ \\
\hline $\begin{array}{l}\text { Increased ability to } \\
\text { compete }\end{array}$ & 2.21 & 2 & 2.40 & 1 & 1 & 0.19 & $\begin{array}{c}\text { Not } \\
\text { significant }\end{array}$ \\
\hline $\begin{array}{l}\text { Greater access to a } \\
\text { wider range of } \\
\text { markets }\end{array}$ & 2.23 & 3 & 2.49 & 3 & 0 & 0.26 & $\begin{array}{c}\text { Not } \\
\text { significant }\end{array}$ \\
\hline Increased sales & 2.23 & 3 & 2.40 & 1 & 2 & 0.17 & $\begin{array}{c}\text { Not } \\
\text { significant }\end{array}$ \\
\hline $\begin{array}{l}\text { Improved distribution } \\
\text { channels }\end{array}$ & 2.36 & 4 & 2.55 & 4 & 0 & 0.19 & $\begin{array}{c}\text { Not } \\
\text { significant }\end{array}$ \\
\hline $\begin{array}{l}\text { Increased flexibility } \\
\text { in communicating } \\
\text { with business } \\
\text { partners }\end{array}$ & 2.43 & 5 & 2.64 & 5 & 0 & 0.21 & $\begin{array}{c}\text { Not } \\
\text { significant }\end{array}$ \\
\hline $\begin{array}{l}\text { Provide managers } \\
\text { better access to } \\
\text { information }\end{array}$ & 2.47 & 6 & 2.72 & 9 & -3 & 0.25 & $\begin{array}{c}\text { Not } \\
\text { significant }\end{array}$ \\
\hline $\begin{array}{l}\text { Improved } \\
\text { relationships with } \\
\text { business partners }\end{array}$ & 2.49 & 7 & 2.68 & 7 & 0 & 0.19 & $\begin{array}{c}\text { Not } \\
\text { significant }\end{array}$ \\
\hline $\begin{array}{l}\text { Improved } \\
\text { communication } \\
\text { within my } \\
\text { organization } \\
\end{array}$ & 2.60 & 8 & 2.74 & 10 & -2 & 0.14 & $\begin{array}{c}\text { Not } \\
\text { significant }\end{array}$ \\
\hline $\begin{array}{l}\text { More effective } \\
\text { support role to } \\
\text { operations }\end{array}$ & 2.62 & 9 & 2.70 & 8 & -1 & 0.08 & $\begin{array}{c}\text { Not } \\
\text { significant }\end{array}$ \\
\hline $\begin{array}{l}\text { Improved } \\
\text { productivity of the } \\
\text { managers }\end{array}$ & 2.64 & 10 & 2.89 & 12 & -2 & 0.39 & $\begin{array}{c}\text { Not } \\
\text { significant }\end{array}$ \\
\hline $\begin{array}{l}\text { Increased cost } \\
\text { reduction }\end{array}$ & 2.66 & 11 & 2.66 & 6 & 5 & 0.00 & Significant* \\
\hline $\begin{array}{l}\text { Provide managers } \\
\text { access to methods } \\
\text { and models in } \\
\text { making functional } \\
\text { area decisions }\end{array}$ & 2.74 & 12 & 2.72 & 9 & 3 & 0.02 & Significant* \\
\hline $\begin{array}{l}\text { Greater ability to join } \\
\text { supply chains of large } \\
\text { companies }\end{array}$ & 2.81 & 13 & 2.85 & 11 & 2 & 0.04 & Significant* \\
\hline $\begin{array}{l}\text { Support for strategic } \\
\text { decision making by } \\
\text { managers }\end{array}$ & 2.83 & 14 & 2.85 & 11 & 3 & 0.02 & Significant* \\
\hline
\end{tabular}


Table 4: Expected and Experienced Barriers

\begin{tabular}{|c|c|c|c|c|c|c|c|}
\hline \multirow[t]{2}{*}{ Barriers } & \multicolumn{2}{|c|}{$\begin{array}{l}\text { Expected } \\
\text { Barrier }\end{array}$} & \multicolumn{2}{|c|}{$\begin{array}{l}\text { Experienced } \\
\text { Barrier }\end{array}$} & \multirow{2}{*}{$\begin{array}{c}\text { Rank } \\
\text { Difference }\end{array}$} & \multirow{2}{*}{$\begin{array}{c}\text { Mean } \\
\text { Difference } \\
\text { (P-Value) }\end{array}$} & \multirow[t]{2}{*}{ Remarks } \\
\hline & Mean & Rank & Mean & Rank & & & \\
\hline $\begin{array}{l}\text { Lack of time to implement } \\
\text { e-business }\end{array}$ & 2.64 & 1 & 2.79 & 5 & -4 & 0.15 & $\begin{array}{c}\text { Not } \\
\text { significant }\end{array}$ \\
\hline $\begin{array}{l}\text { The high level of } \\
\text { complexity associated with } \\
\text { e-business implementation }\end{array}$ & 2.70 & 2 & 2.79 & 5 & -3 & 0.09 & $\begin{array}{c}\text { Not } \\
\text { significant }\end{array}$ \\
\hline $\begin{array}{l}\text { High implementation cost } \\
\text { associated with e-business } \\
\text { technologies }\end{array}$ & 2.72 & 3 & 2.77 & 4 & -1 & 0.05 & $\begin{array}{c}\text { Not } \\
\text { significant }\end{array}$ \\
\hline $\begin{array}{l}\text { Lack of technical expertise } \\
\text { to engage in e-business }\end{array}$ & 2.74 & 4 & 2.68 & 1 & 3 & 0.06 & $\begin{array}{c}\text { Not } \\
\text { significant }\end{array}$ \\
\hline $\begin{array}{l}\text { Resistance to changing work } \\
\text { practices due to e-business } \\
\text { technologies adoption }\end{array}$ & 2.74 & 4 & 3.62 & 11 & 7 & 0.88 & $\begin{array}{c}\text { Not } \\
\text { significant }\end{array}$ \\
\hline $\begin{array}{l}\text { Lack of compatibility } \\
\text { between our current } \\
\text { technical infrastructure and } \\
\text { e-business technologies }\end{array}$ & 2.77 & 5 & 2.74 & 3 & 2 & 0.03 & Significant* \\
\hline $\begin{array}{l}\text { Management concerns about } \\
\text { e-business security }\end{array}$ & 2.81 & 6 & 2.89 & 6 & 0 & 0.08 & $\begin{array}{c}\text { Not } \\
\text { significant }\end{array}$ \\
\hline $\begin{array}{l}\text { Lack of sufficient interest of } \\
\text { your major business partners } \\
\text { to participate in e-business } \\
\text { initiatives }\end{array}$ & 2.83 & 7 & 3.06 & 8 & -1 & 0.23 & $\begin{array}{c}\text { Not } \\
\text { significant }\end{array}$ \\
\hline $\begin{array}{l}\text { Lack of financial resources } \\
\text { to engage in e-business }\end{array}$ & 2.85 & 8 & 2.70 & 2 & 6 & 0.15 & $\begin{array}{c}\text { Not } \\
\text { significant }\end{array}$ \\
\hline $\begin{array}{l}\text { Lack of interest (adoption) } \\
\text { in your industry sector (e.g. } \\
\text { partner) }\end{array}$ & 2.85 & 8 & 3.11 & 10 & -2 & 0.26 & $\begin{array}{c}\text { Not } \\
\text { significant }\end{array}$ \\
\hline $\begin{array}{l}\text { Lack of sufficient planning, } \\
\text { foresight and strategy for e- } \\
\text { business }\end{array}$ & 2.89 & 9 & 2.91 & 7 & 2 & 0.02 & Significant* \\
\hline Lack of industry trust & 2.91 & 10 & 3.11 & 10 & 0 & 0.2 & $\begin{array}{c}\text { Not } \\
\text { significant }\end{array}$ \\
\hline $\begin{array}{l}\text { Your business model is not } \\
\text { suitable to adopting e- } \\
\text { business technologies }\end{array}$ & 2.96 & 11 & 3.09 & 9 & 2 & 0.13 & $\begin{array}{c}\text { Not } \\
\text { significant }\end{array}$ \\
\hline $\begin{array}{l}\text { Lack of management } \\
\text { willingness to engage in e- } \\
\text { business }\end{array}$ & 3.00 & 12 & 2.77 & 4 & 8 & 0.23 & $\begin{array}{c}\text { Not } \\
\text { significant }\end{array}$ \\
\hline $\begin{array}{l}\text { Inadequate competition in } \\
\text { your industry }\end{array}$ & 3.04 & 13 & 3.09 & 9 & 4 & 0.05 & $\begin{array}{c}\text { Not } \\
\text { significant }\end{array}$ \\
\hline
\end{tabular}


Drawing on Table 4, it can be seen that the top five expected barriers (i.e. a lack of time to implement e-business, the high level of complexity associated with e-business implementation, high implementation cost associated with e-business technologies, lack of technical expertise to engage in e-business and resistance to changing work practices due to e-business technologies adoption) substantially differ from the top five experienced barriers (i.e. a lack of technical expertise to engage in e-business, a lack of financial resources to engage in e-business, a lack of compatibility between our current technical infrastructure and e-business technologies, high implementation cost associated with e-business technologies and the high level of complexity associated with $e$-business implementation).

\section{Discussion}

The most important benefits which received the top five ranks in both expected and experienced benefits lead to the following two observations: firstly, providing customers with improved services through e-business technology seems to be the most wanted and achieved benefit; secondly, the remaining four top benefits (both expected and experienced) are internally focused. In a comprehensive review of the benefits businesses gain from investing in IT, Melville et al. (2004) identify three levels of benefits: focal businesses(the organization that invests in and deploys IT resources); level of competitive environment (separated into two components: industry characteristics and trading partners - industry characteristics include competitiveness, technological change, and other factors that shape the way in which IT is applied within the focal firm to generate business value and also include the focal firm's trading partners) and macro environment (specific factors shape IT application for the improvement of organizational performance). All five benefits identified in this study are at the level of the competitive environment. This seems to indicate that the participating SME suppliers have a broader view than just cost savings. This is in contrast to the commonly held view by scholars (Kaynak el al., 2005) that SME suppliers are generally more concerned with obtaining immediate short term benefits from innovative technology such as e-business technology.

Furthermore, there is evidence of seeking and experiencing both strategic (e.g. increased ability to compete and greater access to a wider range of markets) and efficiency improvement oriented benefits (improved distribution channels and increased flexibility in communication with business partners). This observation is consistent with the views expressed by such scholars as Quayle (2002), Fillis et al. (2004) and Riquelme (2002). Interestingly, the participating SME suppliers seemed to have given higher priority to satisfying the needs of their customers rather than enhancing their internal productivity and decision making capabilities using ebusiness technologies.

Table 3 further indicates that out of fifteen benefits, the difference in ranks of four benefits (i.e. increased cost reduction, provide managers access to methods and models in making functional area decisions, greater ability to join supply chains of large companies and support for strategic decision making by managers) are statistically significant. A close look at these four specific benefits indicates that: the SME suppliers did not expect to gain an improvement in the decision making capabilities of their functional and strategic management as a result of introducing ebusiness technologies. However, in real life, these two benefits were significantly experienced. This observation is in line with research on the business value of IT (e.g. Melville et al., 2004). The use of IT to change organizational processes can have a ripple effect onto other non related processes. Scheepers and Scheepers (2008) highlight the ripple effect the introduction of e-business technology can have on various processes even though these processes have not been directly changed by technology. It is possible that participating suppliers have experienced such a ripple effect by utilizing e-business technology to enhance their customer service. The technology potentially 
increased the efficiency and effectiveness of other processes in the supplier and provides managers with spin-off information assets that can be utilized quite effectively (Scheepers \& Scheepers, 2008).

The SME suppliers did not expect a reduction in their operating costs as a result of e-business technology adoption but they have experienced a reduction in costs once the technology was put into operation. This may be attributed to the fact that e-business technologies, through improving customer services, may have reduced the need for additional paper work which was necessary to resolve customer complaints. This could also be due to the lesser need to maintain customer service staff who are often dispatched to the customer's premises for face-to-face discussion.

The findings further suggest that although the SME suppliers recognized the high level of complexity associated with e-business implementation to be a major barrier they assumed that they have the technological sophistication and maturity to manage the introduction and operation those complex applications. They also underestimated the financial commitment required for introducing e-business technologies which is not surprising given that they have limited understanding about the hidden cost associated with e-business technologies adoption.

From Table 4, it appears that out of fifteen barriers, the difference in the ranks of two particular barriers (i.e. lack of compatibility between our current technical infrastructure and e-business technologies and lack of sufficient planning, foresight and strategy for e-business) are statistically significant. This is in fact suggests that the participating SME suppliers were potentially ill-prepared for the introduction of e-business technologies. They have seriously underestimated the importance of adequate upfront planning activities in support of e-business technology adoption.

\section{Conclusion}

The rapid spread of the Internet as a low cost business medium has improved awareness of electronic business which attracted SMEs to invest in various forms of e-business technologies. However, gaining benefits from the adoption of these technologies is not easy as SMEs need to overcome many barriers associated with their implementation. Although there exists some literature on SMEs' perceptions about benefits and barriers, past studies did not differentiate between buyers and suppliers. In particular, little has been investigated from the perspective of SME suppliers. To address this gap in the literature, this project was initiated to better understand the perceptions of SME suppliers about ebusiness adoption benefits and barriers. Understanding the views of SME suppliers is important because the full potential of ebusiness can be realized when both buyers and suppliers appreciate the value of ebusiness and are aware of the potential difficulties in adopting e-business technologies and prepare themselves accordingly.

Several interesting findings have emerged from our study which was discussed in light of the existing literature. However, our interpretation of the findings should be treated with caution due to the selection of a convenient and small sample from only a particular location (i.e. Victoria) in Australia. However, we do not see any reason for which SMEs located in other parts of Australia would differ significantly from those located in Victoria. This is because the operating and competitive forces which help shape SME industry are likely to be equally applicable to all states of Australia. Therefore, despite acknowledging the limitation associated with small sample size, we may still be able to safely extend our observations about ebusiness adoption benefits and barriers to broader Australian SME context. However, the findings may not be applicable to other national context without further empirical confirmation. Another weakness of this study is the implicit assumption that participant's experience correlates with their expertise. However, expertise of 
participants may differ from their working experience at their respective organizations which may in turn interfere in completing the survey instrument. Despite these limitations, we believe that our findings are useful to both theory and practice. For theory, this research highlights the benefits and barriers from the perspective of SME suppliers which has not been specifically addressed in the existing e-business literature. As the ebusiness literature is primarily concerned with the benefits and problems faced by buyers, this study helps in reducing a gap in the literature. With regard to practice, the findings would help raise awareness of SME management about the key issues associated with e-business adoption and thus help set realistic expectations from their investment decisions in e-business technology.

There are several ways to extend our work. There is a clear need to increase sample size and conduct qualitative case studies. Together, they would help us improve generalization of the research findings. Further studies are needed to investigate the ripple effect of e-business technology investment on organizational processes. This research indicated that SME suppliers in Victoria, Australia have a long term view of utilizing e-business technologies. Additional studies are required to further explore this phenomenon in contexts other than Australia.

\section{References}

Argoneto, P. and P. Renna (2010). "Production planning, negotiation and coalition integration: A new tool for an innovative e-business model." Robotics and Computer-Integrated Manufacturing 26(1): $1-12$.

Church, A. (1993). "Estimating the effect of incentives on mail survey response rates: $\mathrm{A}$ meta-analysis." Public Opinion Quarterly 57(1): 62.

Davies, A. J. and Garcia-Sierra, A. J. (1999). Implementing electronic commerce in
SMEs - three case studies. BT Technology Journal, 17(3): 97-111

Drew, S. (2003). Strategic Uses of ECommerce by SMEs in the East of England. European Management Journal, 21(1): 7988.

Dubelaar, C., A. Sohal, et al. (2005). "Benefits, impediments and critical success factors in B2C E-business adoption." Technovation 25(11): 1251-1262.

Grant, Robert M. (1991) "The resourcebased theory of competitive advantage: Implications for strategy formulation". California Management Review, 33(3), Spring, pp. 114-135.

Grover, V. and P. Ramanlal (1999). "Six Myths of Information and Markets: Information Technology Networks, Electronic Commerce, and the Battle for Consumer Surplus." MIS Quarterly 23(4): 465-495.

Gunasekaran, A. and Ngai, E. W. T. (2007). Adoption of e-procurement in Hong Kong: an empirical research. International Journal of Production Economics, 113: 159-175.

Heung, V. C. S. (2003). Barriers to Implementing E-Commerce in the Travel Industry: A Practical Perspective. International Journal of Hospitality Management, 22(1): 111-118.

Fillis, I., Johannson, U. et al. (2004). Factors impacting on e-business adoption and development in the smaller firm. International Journal of Entrepreneurial Behaviour \& Research, 10(3): 178 - 191.

Johnson, M. (2010). "Barriers to innovation adoption: a study of e-markets." Industrial Management \&\# 38; Data Systems 110(2): 157-174.

Kaynak, E., Tatoglu, E. et al. (2005). An analysis of the factors affecting the adoption of electronic commerce by SMEs: Evidence from an emerging market. International Marketing Review, 22(6): 623 $-640$. 
Khatibi, A., V. Thyagarajan, et al. (2003). "Ecommerce in Malaysia: Percieved Benefits and Barriers " Interfaces Journal 28(3).

Kartiwi, M. and MacGregor, R. C. (2007). Electronic Commerce Adoption Barriers in Small to Medium-Sized Enterprises (SMEs) in Developed and Developing Countries: A Cross-Country Comparison. Journal of Electronic Commerce in Organizations, 5(3): $35,17$.

Kaynak, E., Tatoglu, E. et al. (2005). An analysis of the factors affecting the adoption of electronic commerce by SMEs: Evidence from an emerging market. International Marketing Review, 22(6): 623 $-640$.

Li, W. and McQueen, R. J. (2008). Barriers to mobile commerce adoption: an analysis framework for a country-level perspective. International Journal of Mobile Communications, 6(2).

Melville, N., Kraemer, K. and Gurbaxani, V. (2004). Review: Information technology and orgnizational performance: an integrative model of IT business value. MIS Quarterly, 28(2), 283-322.

NOIE (2000). Taking the Plunge - Sink or Swim: Attitudes and Experiences of SMEs to E-business. Retrieved 20 March, 2004 from:

http://www.noie.gov.au/publications/inde $\underline{\text { x.htm }}$

Osmonbekov, T. (2010). "Reseller adoption of manufacturers'e-business tools: The impact of social enforcement, technologyrelationship fit and the mediating role of reseller benefits." \ournal of Business Research 63(3): 217-223.

Quayle, M. (2002). E-commerce: the challenge for UK SMEs in the twenty-first century. International Journal of Operations \& Production Management, 22(10): 1148 1161.

Riquelme, H. (2002). Commercial Internet adoption in China: comparing the experience of small, medium and large businesses. Internet Research, 12: 276 286.
Scheepers, H. and Scheepers, R. (2008). A process-focused decision framework for analyzing the business value potential of IT investments. Information Systems Frontiers, 10(3), 321-330.

Scupola, A. (2009). SMEs' e-commerce adoption: perspectives from Denmark and Australia. Journal of Enterprise Information Management, 22(1/2): 152-166.

Tan, K., S. Chong, et al. (2010). "Internetbased ICT adoption among SMEs." Management 23(1): 27-55.

Tan, K. S., Chong, S. C. et al. (2009). Internet-based ICT adoption: evidence from Malaysian SMEs. Industrial Management \& Data Systems, 109(2): 224 244.

Tan, J. K., Tyler et al. (2007). Business-tobusiness adoption of ecommerce in China. Information \& Management, 44(3): 332-51.

Tan, Y. L., L. A. (2007). Adoption of ICT among small business: vision vs. reality. International Journal of Electronic Business 5(2): 188-203.

Wright, K. B. (2005). Researching Internetbased populations: Advantages and disadvantages of online survey research, online questionnaire authoring software packages, and web survey services. Journal of Computer-Mediated Communication, 10(3).

Yun, G. W. and Trumbo, C. W. (2000). Comparative response to a survey executed by post, email, and web form. Journal of Computer-Mediated Communication, 6(1). 